\title{
Evolution of glaciation in the Pamiro-Alai mountains and its effect on river run-off
}

\author{
V. G. Konovalov and A. S. Shchetinnicov \\ Central Asian Regional Research Hydrometeorological Institute (SANIGMI), 700052 Tashkent, Uzbekistan
}

\begin{abstract}
The aim of the present research is to evaluate changes in the glacierized area, glacier-water resources and glacial run-off during the last 25-30 years. The prevailing process of degradation has resulted in a $16 \%$ diminution of the glacierized area in Gissaro-Alai and $11 \%$ in the Pamirs. The ratio between the advancing, stationary and retreating glaciers in the Gissaro-Alai mountains is $1: 5: 17$, and the one in the Pamirs is $1: 1: 4$. Moraine-covering of the glaciers has increased from 8 to $11 \%$ in the Gissaro-Alai and from 6 to $11 \%$ in the Pamirs. Icevolume diminution of glaciers in the Gissaro-Alai is $17 \%$ and in the Pamirs it is $12 \%$. The mean long-term annual volume of total glacial melting, glacial run-off and variation coefficients of these values in the river basins of the Pamirs and the GissaroAlai are described as functions of the altitudes of glacier termini, equilibrium lines and a new parameter, which characterizes the influence of the glacierized area distribution according to altitude on run-off. The data presented here indicate changes in mean annual volumes of glacier water yield in the river basins of the Pamirs and the Gissaro-Alai mountains, related to glaciation evolution in 1957-80.
\end{abstract}

\section{GENERAL}

The Pamiro-Alai mountains have the most extensive glacierized area amongst the other mountains in the U.S.S.R. Sufficiently complete information on the sizes of glaciers in the basins of the Pjange, Vakhsh and Zeravshan Rivers, as well as of the southern part of the Fergana Valley and several others situated within the Pamiro-Alai system was obtained from data from airphotograph surveys in 1957-59 and used to compile the U.S.S.R. inventory of glaciers. Furthermore, these data were used to define average values of glacial nourishment of rivers in Central Asia and their long-term variations. It has been defined, in particular that, in 1935-89, the average contribution of run-off from the glacierized areas in the major basins in the Pamirs and Gissaro-Alai into the total run-off for the June-September period is as follows:

In the basin of the Pjange River (Nizni Pjange gauge) $41 \%\left(7.7 \mathrm{~km}^{3}\right)$.

In the basin of the Vakhsh River (Komsomolabad gauge) $44 \%\left(5.7 \mathrm{~km}^{3}\right)$.

In the basin of the Zeravshan River (Dupuli gauge) $43 \%\left(1.5 \mathrm{~km}^{3}\right)$.

In extremely low-flow years, the role of glacial nourishment in June-September is very important. Table 1 presents data on glacial run-off for a number of such years. It is seen that in the years with negligible winter-spring accumulation of precipitation the rate of stream flow in June-September is mainly provided by run-off from glacierized areas.

In the middle $1980 \mathrm{~s}$, an integrated cartographic inventory of natural resources in the Pamiro-Alai mountains (scale of 1:500000), including contemporary glacierized areas, was made on the basis of the wide application of space and air photography of the Earth's surface. The work carried out within this project and observations on fluctuations of the glaciers in the PamiroAlai mountains were within the framework of the International Programme and allowed us to reach certain conclusions about the continuing reduction of glacierized areas which had begun in the early 20th century, resulting in a decrease of water storage in the glaciers.

Thus, data in the U.S.S.R. inventory of glaciers on extent of glaciation are at present obsolete, so in 1986-90 they have been corrected for the territory of the Pamiro-Alai mountains in the Glaciology Department of our Institute (SANIGMI).

The modified information on morphometry of glacierized area in the Pamiro-Alai mountains was used to assess the effect of glaciation evolution on the run-off of the rivers. The work completed is extensive in that there is no analogous one in the U.S.S.R. and over the whole world. Here, we bear in mind that the repeated assessment of area and altitudinal characteristics is being made for several thousands of glaciers $(>10000)$. Figure 1 shows the general view of the locations of the main ranges, glacierized regions, hydrological gauges and meteorological stations within the Pamiro-Alai mountains. Data 
Table 1. Relative (\%) and absolute $\left(\mathrm{km}^{3}\right)$ contributions of glacial nourishment to total run-off of the main rivers in the Pamir-Alai mountains during June-September in low-flow years

\begin{tabular}{lcccccc}
$\begin{array}{l}\text { River } \\
\text { (gauge station) }\end{array}$ & 1938 & 1944 & 1947 & 1961 & 1971 & 1978 \\
\hline $\begin{array}{l}\text { Pjange } \\
\text { (Nizni Pjange) }\end{array}$ & $\frac{60}{10.4}$ & $\frac{56}{11.4}$ & $\frac{60}{13.5}$ & $\frac{72}{15.4}$ & $\frac{65}{13.9}$ & $\frac{55}{12.6}$ \\
$\begin{array}{l}\text { Vakhsh } \\
\text { (Komsomolabad) }\end{array}$ & $\frac{40}{4.5}$ & $\frac{64}{9.1}$ & $\frac{74}{8.2}$ & $\frac{72}{8.6}$ & $\frac{62}{7.6}$ & $\frac{71}{10.1}$ \\
$\begin{array}{l}\text { Zeravshan } \\
\text { (Dupuli) }\end{array}$ & $\frac{54}{1.5}$ & $\frac{61}{2.0}$ & $\frac{59}{1.9}$ & $\frac{58}{1.9}$ & $\frac{44}{1.6}$ & $\frac{50}{2.4}$
\end{tabular}

Note. The numerator is the relative run-off contribution (\%) from the glacierized area to total run-off in the basin for June-September; the denominator is the total run-off volume from the glacierized area in $\mathrm{km}^{3}$ as input to the river nourishment.

on areal and altitudinal characteristics of the glacierized areas in the river basins of the Pamiro-Alai mountains are given in Tables $2-4$.

\section{VARIATION IN THE GLAGIERIZED AREA IN THE GISSARO-ALAI MOUNTAINS DURING 1957-80}

The modified data in the U.S.S.R. inventory of glaciers indicate that in 1957-59 there were 4287 glaciers in the river basins of the Gissaro-Alai mountains, having a total area of $2183.5 \mathrm{~km}^{2}$. Table 2 gives information on the area of glaciers in separate basins at the beginning and the end of the given period. This table indicates a noticeable reduction in the glacierized area in all river basins where glaciers with areas up to $2.0 \mathrm{~km}^{2}$ are prevalent. About one-third of the reduced glaciation area $(36 \%)$ refers to the river basins situated on the northern slopes of the Turkestansky and Alaisky Ridges: $61 \%$ to the basins of the Amudarya River tributaries and $3 \%$ to the Kashgarskaya Kizilsu River basins.

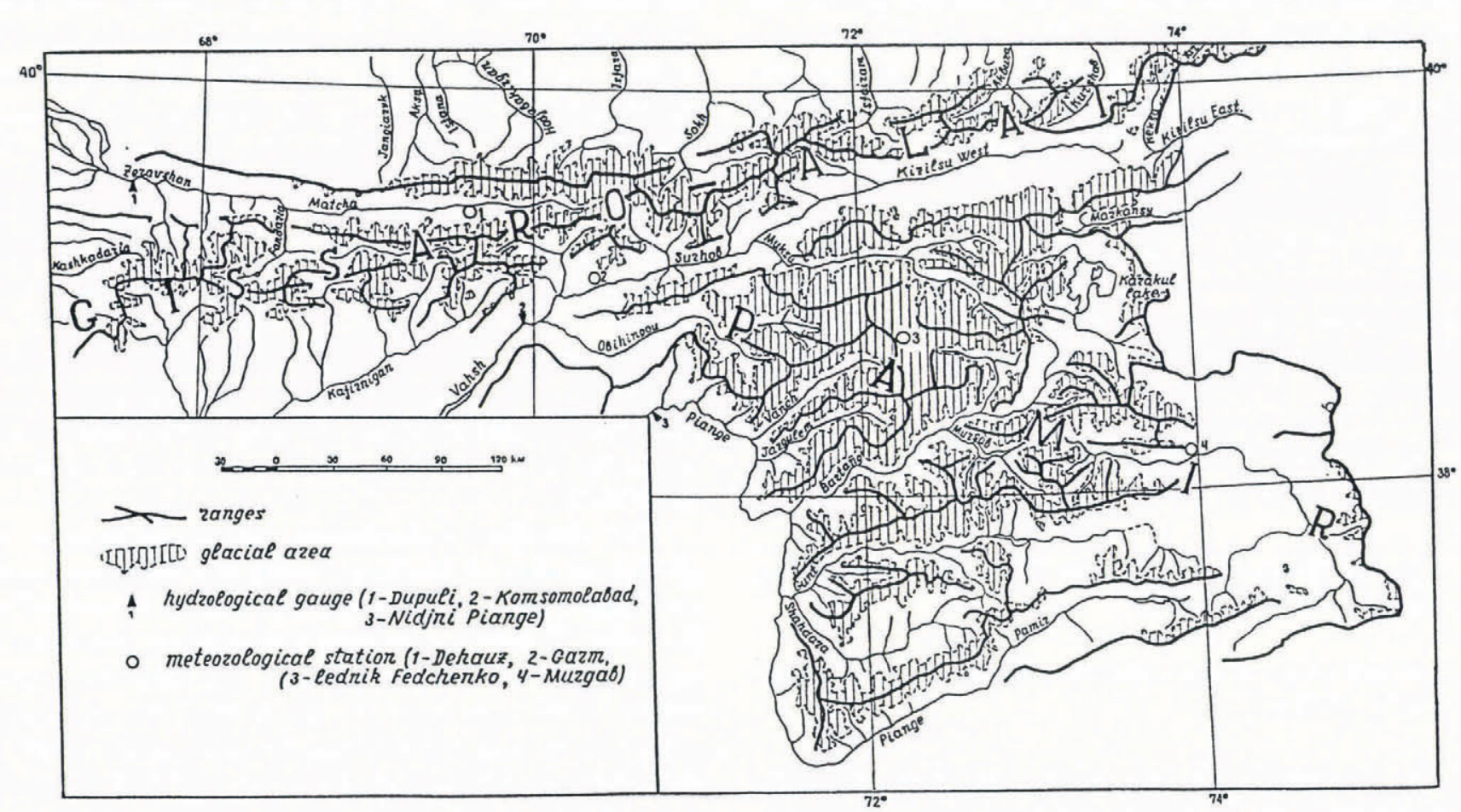

Fig. 1. Schematic representation of glacierized regions in the Pamir and Gissaro-Alai mountains. 
Table 2. Variation in glacierized area and altitudes of glacier termini in the river basins of the Gissaro-Alai in 1957-80

River basin

Area of glaciers, $F$

$\begin{array}{lllll}\text { Beginning } & \text { End } & \Delta F & \text { Beginning } & \text { End } \\ & \mathrm{km}^{2} & \mathrm{~km} \text { a.s.l. }\end{array}$

Altitudes of termini

\begin{tabular}{|c|c|c|c|c|c|c|}
\hline 1 & Jangiaryk & 0.3 & 0.2 & -0.1 & 3.84 & 3.84 \\
\hline 2 & Aksu & 16.3 & 12.1 & -4.2 & 3.76 & 3.80 \\
\hline 3 & Isfana & 0.3 & 0.2 & -0.1 & 3.74 & 3.71 \\
\hline 4 & Hodjabakirgan & 42.4 & 37.4 & -5.0 & 3.73 & 3.69 \\
\hline 5 & Isfara & 129.7 & 124.5 & -5.2 & 3.59 & 3.55 \\
\hline 6 & Karakol & 0.2 & 0.1 & -0.1 & 3.48 & 3.53 \\
\hline 7 & Karabulak & 0.1 & 0.1 & 0 & 3.61 & 3.62 \\
\hline 8 & Sokh & 279.3 & 241.9 & -37.4 & 3.53 & 3.52 \\
\hline 9 & Shahimardan & 39.5 & 30.1 & -9.4 & 3.91 & 3.96 \\
\hline 10 & Isfairamsay & 88.6 & 66.2 & -22.4 & 4.05 & 4.10 \\
\hline 11 & Aravansay & 58.0 & 50.0 & -8.0 & 3.99 & 4.02 \\
\hline 12 & Akbura & 85.2 & 63.5 & -21.7 & 4.10 & 4.11 \\
\hline 13 & Kurshab & 16.4 & 9.4 & -7.0 & 3.85 & 3.94 \\
\hline 14 & Tar & 23.4 & 20.5 & -2.9 & 3.98 & 3.99 \\
\hline 15 & Zeravshan (Matcha) & 504.8 & 438.0 & -66.8 & 3.57 & 3.51 \\
\hline 16 & Fandaria & 133.4 & 100.8 & -32.6 & 3.71 & 3.73 \\
\hline 17 & Zeravshan's left tributary & 43.0 & 34.9 & -8.1 & 3.64 & 3.68 \\
\hline 18 & Kashkadaria & 18.2 & 15.5 & -2.7 & 3.64 & 3.67 \\
\hline 19 & Surhandaria & 70.2 & 59.3 & -10.9 & 3.71 & 3.73 \\
\hline 20 & Kafirnigan & 111.5 & 83.7 & -27.8 & 3.61 & 3.64 \\
\hline 21 & Surhob's right tributary & 386.2 & 341.9 & -44.3 & 3.57 & 3.57 \\
\hline 22 & Western Kizilsu & 114.0 & 94.8 & -19.2 & 3.94 & 3.94 \\
\hline 23 & Keksu & 22.8 & 13.8 & -9.0 & 4.04 & 4.08 \\
\hline & Total & 2183.8 & 838.9 & -344.9 & & \\
\hline & Moraine area & 166.8 & 195.8 & 28.6 & & \\
\hline
\end{tabular}

Note. "Beginning" relates to 1957 , "end" to 1980 and $\Delta F$ is change in glacierized area.

In the period considered here, $19 \%$ of the glaciers remained stationary, $4 \%$ advanced and $69 \%$ retreated in the Gissaro-Alai mountains region. The reduction in the area occurred not only along the fronts of the lower parts of the glacier tongues but also in the glaciers' nourishment areas. Despite various forms of glacier degradation, $84 \%$ of the reduced area of the glaciers belong to both the tongues and glaciers as a whole.

The process of degradation was followed either by reduction in the glacierized area in 1957-80 and/or by an increase in the extent of glacier moraine. Above an altitude of $2.8 \mathrm{~km}$, the moraine area has increased as follows: up to $3 \mathrm{~km}$ - by $17 \%$, from 3.0 to $4.0 \mathrm{~km}$ by $15 \%$, above $4.0 \mathrm{~km}$ - by $35 \%$ compared with the moraine area in 1957. The upper moraine limit became $300 \mathrm{~m}$ higher, namely, from 4.5 to $4.8 \mathrm{~km}$. The degree of moraine coverage of glaciers, being the ratio between moraine area and glacier area, has increased from 8 to $10 \%$.

In the period considered, mass decrease of glaciers in the Gissaro-Alai mountains was $17 \%$ of the initial volume. This means $15 \mathrm{~km}^{3}$ of water. For 1980 , the ice volume in the glaciers of Gissaro-Alai is estimated as $87.5 \mathrm{~km}^{3}$.

\section{VARIATION OF SIZES AND WATER RES- OURCES OF THE GLACIERIZED AREA IN THE PAMIRS IN 1957-80}

In the Pamirs, the glacierized area has been reduced by $10 \%$ during the period $1957-80$. The ratio between advancing, stationary and retreating glaciers is $1.0: 0.7: 4.1$. Table 3 gives information on the glacierized areas in individual basins at the beginning and the end of the period being considered. The number of glaciers there in relation to 1980 is 7260 .

The altitudinal distribution of the reduced glacierized area is as follows: below $3.0 \mathrm{~km}, 0.03 \%$; from 3.0 to $4.0 \mathrm{~km}, 70.5 \%$; from 5.0 to $6.0 \mathrm{~km}, 17.6 \%$; above $6.0 \mathrm{~km}$, the glacierized area increased by $4.35 \mathrm{~km}^{2}$.

The degree of moraine coverage of glaciers increased 
Table 3. Variation in glacierized area and altitudes of glacier termini in the Pamir mountains in 1957-80

Basins

Area of glaciers, $F$

Altitudes of termini

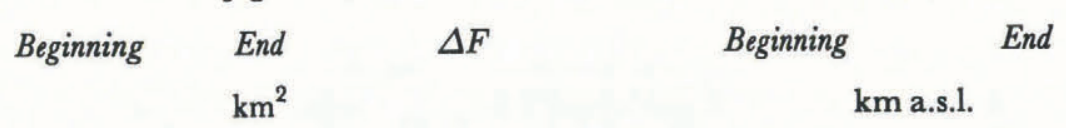

\section{Kizilsu East}

2 Kizilsu West

3 Markansu

4 Karakul Lake

5 Muksu

6 Fedchenko glacier

7 Obihingou

8 Ptr (1)

9 Vanch

10 Jazgulem

11 Bartang

12 Ptr (2)

13 Murgab

14 Gunt

15 Shahdara

16 Ptr (3)

Total

Moraine area
145.0

526.9

171.0

395.5

1272.0

753.3

806.7

23.5

343.7

330.8

1082.8

45.0

370.8

534.8

215.9

244.2

7361.8

320.0

\section{5}

487.3

171.7

381.5

1239.5

759.3

706.3

19.9

291.5

263.7

930.5

39.2

387.1

441.2

166.3

184.0

6600.4

664.1
$-13.5$

$-39.6$

0.7

$-14.0$

$-32.5$

6.0

$-100.4$

$-3.6$

$-52.2$

$-67.1$

$-152.3$

$-5.8$

$-83.7$

$-93.6$

$-49.6$

$-60.2$

$-761.4$

344.1
3.95

4.04

4.58

4.75

4.23

3.93

3.63

3.86

3.56

3.90

4.26

4.30

4.74

4.59

4.58

4.77

Notes. Ptr (1), Pjange tributaries below the Vanch River mouth; Ptr (2), Pjange tributaries between the Jazgulem, Bartang, Gunt River mouth; Ptr (3), Pjange tributaries over the Gunt River mouth.

from 5 to $11 \%$. Natural pollution of the glacier surface has also increased in a similar way to that in the glaciers of the Gissaro-Alai mountains.

Direct measurements of glacier volumes were not carried out, so their estimation at the beginning and the end of the period was made by indirect methods, taking into account sizes and other morphometric parameters of the glaciers. Formulae of Nye (1952), Yerasov (1968), Steinhauser (1970), Mazo and Glazyrin (1986) were used.

From the Nye formulae, glacier thickness is determined by the sine of its slope angle

$$
H=11.3 / \sin \alpha
$$

where $H$ is the mean thickness of a glacier, $\sin \alpha$ is the sine of its slope angle, which is computed from the length $L$, and the values of the upper $Z_{\max }$ and $Z_{\min }$ points of the glacier:

$$
\sin \alpha=\frac{Z_{\max }-Z_{\min }}{\sqrt{\left(Z_{\max }-Z_{\min }\right)^{2}+L^{2}}} .
$$

It follows from Equations (1) and (2) that the volume $V$ of a glacier having an area $F$ is

$$
V=\frac{11.3 F \sqrt{\left(Z_{\max }-Z_{\min }\right)^{2}+L^{2}}}{Z_{\max }-Z_{\min }} .
$$

Yerasov's (1968) formulae relate glacier volume $V\left(\mathrm{~km}^{3}\right)$ to its area $F$ :

$$
V=0.027 F^{1.5} \text {. }
$$

Steinhauser's (1970) formulae relate glacier thickness $H$ to its area $F$ :

$$
H=11.7+5.67 F \text {. }
$$

Finally, Mazo and Glazyrin's (1986) formulae take into account not only sizes and morphological parameters of a glacier but also the value of the amount of nourishment $P$ :

$$
\left.V=\left(1.63 F H_{0}\right) \times 10^{-3} /[(1+D Z)] / H_{0}\right]^{0.774}
$$

where $D Z=Z_{\max }-Z_{\min }$ is the vertical range of the glacier, $H_{0}=0.073 \sqrt{X_{0}}$, where $X_{0}$ is the glacier length in km.

The value of $P$ being known, calculations of volume are made by using Equation (6), while

$$
H_{0} \sim 2.30 X_{0}^{\frac{1}{2}} F_{0}^{\frac{1}{8}}
$$

where $F_{0}=2 P$.

The above-mentioned indirect ways of calculation resulted in a wide range of scattering in the values: the minimum ones are the estimations using Steinhauser's formulae, the maximum by Mazo and Glazyrin's 
formulae. That is why averaging of the computation results using all four methods was done for the estimation of the total ice volume of all the glaciers of the mountain system.

The ice volume of the glaciers of the Pamiro-Alai mountains was $468.2 \mathrm{~km}^{3}$ in 1980 . In the period considered here there was a decrease in ice of $66 \mathrm{~km}^{3}$ $(13 \%)$ or $56.1 \mathrm{~km}^{3}$ of water, which equals the annual runoff of the Amudarya River at the Kerki gauge $\left(59.9 \mathrm{~km}^{3}\right)$.

\section{HYDROLOGICAL REGIME OF CONTEMPOR- ARY GLACIERIZED AREA IN THE PAMIRO-ALAI MOUNTAINS}

Assessment of variations in the glacierized area in Central Asia and other mountainous regions of the U.S.S.R. is closely related to the main processes of glacier activity. The problem considered here requires a description of the annual course of the glacial run-off in years with different rates of stream flow; the effect of the evolution of the glacierized area on the glacial nourishment of rivers in the Pamirs and Gissaro-Alai mountains is estimated.

Konovalov $(1979,1985)$ has developed a physical and statistical model of accumulation and ablation processes for the integrity of glaciers in a river basin, which at present is used for detailed computation of the annual course and the long-term hydrological regimes in a number of large glacierized regions of Central Asia.

The model describes the annual course of the hydrological regime of a glacierized area and computes $10 \mathrm{~d}$ and monthly hydrographs of melting and run-off as well as total volumes of melted glacial water for MayOctober. Stable parameters for the whole period of computation are used in the model together with information about the annual course of the meteorological elements at a representative alpine station. Generally, it is not difficult to include information on annual or, at least, systematic estimates of morphometric parameters of a glacierized area in the scheme of computation. But, since the time when the U.S.S.R. inventory of glaciers was published, such an investigation has been made for the first time and it is difficult to conceive when regular estimates of glacierized areas of river basins will be made in the future. Therefore, estimates of the effect of the evolution of glaciation on the run-off of rivers in the Pamirs and Gissaro-Alai mountains may be made only for average long-term values.

Table 4 gives only examples of empirical statistics of long-term series of total glacier melting and glacial run-off which were computed using the model of Konovalov (1985) for a number of river basins in the Gissaro-Alai mountains. Similar information was obtained for the main tributaries of the Vakhsh River. The data indicate Table 4. Statistical characteristics of long-term series of annual total glacial melting $\left(V_{\mathrm{m}}\right)$ and glacial run-off $\left(W_{\mathrm{gl}}\right)$ in
some basins of the Gissaro-Alai

\begin{tabular}{|c|c|c|c|c|c|c|c|c|c|c|}
\hline \multirow[b]{2}{*}{ Basin } & \multirow[b]{2}{*}{$N$} & \multirow[b]{2}{*}{$F_{\mathrm{gl}}$} & \multirow[b]{2}{*}{$\bar{V}_{\mathrm{m}}$} & \multicolumn{3}{|c|}{ Parameters of $V_{m}$} & \multirow[t]{2}{*}{$W_{\mathrm{gl}}$} & \multicolumn{3}{|c|}{ Parameters of $W_{\mathrm{gl}}$} \\
\hline & & & & $S T$ & $C_{\mathrm{v}}$ & $C_{\mathrm{B}}$ & & $S T$ & $C_{\mathrm{v}}$ & $C_{\mathrm{s}}$ \\
\hline Sokh & 1 & 21.0 & 80.3 & 17.0 & 0.21 & -0.61 & 19.0 & 18.5 & 0.97 & 0.68 \\
\hline \multirow[t]{4}{*}{$1948-83$} & 2 & 98.3 & 324.0 & 86.5 & 0.27 & -1.34 & 48.4 & 58.9 & 1.22 & 1.07 \\
\hline & 3 & 49.5 & 165.6 & 36.1 & 0.22 & -0.67 & 45.8 & 38.2 & 0.83 & 0.47 \\
\hline & 4 & 84.7 & 236.3 & 57.7 & 0.24 & -0.55 & 35.4 & 30.1 & 0.85 & 1.22 \\
\hline & 5 & 18.3 & 65.5 & 15.6 & 0.24 & -0.55 & 36.3 & 14.2 & 0.39 & -0.37 \\
\hline Matcha & 1 & 219.0 & 628.9 & 125.8 & 0.20 & -0.08 & 176.8 & 124.7 & 0.71 & 0.18 \\
\hline \multirow[t]{4}{*}{$1943-83$} & 2 & 111.0 & 260.5 & 54.7 & 0.21 & 0.05 & 69.9 & 58.8 & 0.84 & 1.18 \\
\hline & 3 & 37.5 & 92.7 & 20.4 & 0.22 & 0.05 & 32.5 & 31.3 & 0.96 & 3.22 \\
\hline & 4 & 86.9 & 210.2 & 48.3 & 0.23 & 0.04 & 48.7 & 38.9 & 0.80 & 0.42 \\
\hline & 5 & 17.7 & 33.2 & 9.3 & 0.28 & 0.20 & 10.5 & 6.2 & 0.59 & 0.25 \\
\hline Fandaria & 1 & 23.9 & 88.0 & 17.0 & 0.19 & -0.10 & 19.5 & 17.9 & 0.92 & 0.59 \\
\hline \multirow[t]{7}{*}{$1943-83$} & 2 & 9.0 & 50.2 & 9.9 & 0.20 & -0.29 & 27.1 & 10.2 & 0.38 & 0.27 \\
\hline & 3 & 41.1 & 144.6 & 27.7 & 0.19 & -0.16 & 18.7 & 20.3 & 1.08 & 1.03 \\
\hline & 4 & 50.6 & 158.2 & 30.2 & 0.19 & -0.07 & 13.6 & 13.3 & 0.98 & 1.07 \\
\hline & 5 & 18.7 & 77.1 & 22.2 & 0.29 & -0.16 & 38.5 & 22.5 & 0.58 & 0.13 \\
\hline & 6 & 10.3 & 34.0 & 6.7 & 0.20 & -0.18 & 10.7 & 5.9 & 0.55 & 0.22 \\
\hline & 7 & 14.0 & 40.4 & 9.2 & 0.23 & -0.01 & 8.2 & 7.5 & 0.91 & 0.65 \\
\hline & 8 & 8.9 & 31.4 & 9.7 & 0.31 & -0.09 & 13.9 & 8.9 & 0.64 & 0.00 \\
\hline
\end{tabular}

Notes. $N$, number of glacier's group; $F$, area of glaciation in $\mathbf{k m}^{2} ; V_{\mathrm{m}}$, mean value of total melting in $\times 10^{6} \mathrm{~m}^{3} ; W_{\mathrm{gl}}$, mean value of glacial run-off in $\times 10^{6} \mathrm{~m}^{3} ; S T$, root-mean-square deviation; $C_{\mathrm{v}}$, coefficient of variation; $C_{8}$, coefficient of skewness. 
that the index of variation $\left(C_{\mathrm{v}}\right)$ for annual total melt volumes changes insignificantly $(0.2-0.3)$ within the glacierized areas in the basins of the Sokh, Kizilsu and Obihingou Rivers. This characteristic is more variable in the basins of the Muksu and Seldara Rivers (Fedchenko glacier).

Long-term fluctuations of glacial run-off in the Pamirs and Gissaro-Alai mountains are almost synchronous in the time interval considered here $\left(C_{\mathrm{v}}\right.$ changes from 0.4 to $1.2)$; it can be explained by the similar climatic conditions in the alpine zone.

The combined analysis of long-term variability of river flow in the Pamiro-Alai mountains and the contribution of glacial run-off and total melting in glacierized areas to feeding rivers during May-October showed the contributions of glacial run-off and total melting increase in low-flow years and decrease in highflow ones. This peculiarity of glacial run-off is extremely important for water supply to users, because it provides natural regulation of run-off.

The values of glacial run-off indicate that, in all the river basins of the Pamirs and the Gissaro-Alai mountains, the years 1954,1958,1969, 1972, 1979 and 1981 are extremely low-flow and 1961 and 1973 are highflow years. The ratio between annual values of glacial run-off in the year with the highest flow to those in the year of the lowest flow is $(25-30): 1$ for the Zeravshan and Vakhsh Rivers.

Analysis of the seasonal course (May-October) of total melt distribution in per cent, and of its components, glacial and snow run-off, total run-off of the Vakhsh River at the Komsomolabad gauge on average, high- and low-flow years, allowed us to reach the following conclusions based on the values of glacial nourishment:

1. The general shape of the graphs, showing the seasonal course of monthly volumes of total melt, snow run-off and total run-off, is stable despite the water yield during the year. Frequency distribution relative to the modal value of the graphs has a more or less symmetric character (see Fig. 2).

2. Maximum values of total melt in the years of average and high flow are observed in August. The river run-off maximum is observed 1 month earlier, coinciding in time with run-off from snowmelt on the glaciers. In low-flow years, the distribution of snow run-off from a glacierized area coincides with the distribution of total melt; it is explained by the negligible volume of icemelt in these years.

3. In high-flow years, the distribution of snow run-off in glacierized regions has sharp rises and falls, whereas in the years of average and maximum water the curve becomes smoothed within a season.

4. In the years of average and high flow, the maximum of glacial nourishment in the river basins of the Pamirs is in August-September when the reserves of winter-spring snow accumulation are pratically exhausted outside the glacierized areas of the watersheds. This conclusion was reached for the first time and stresses once more the vital role of glaciation as a source of river nourishment in Central Asia.
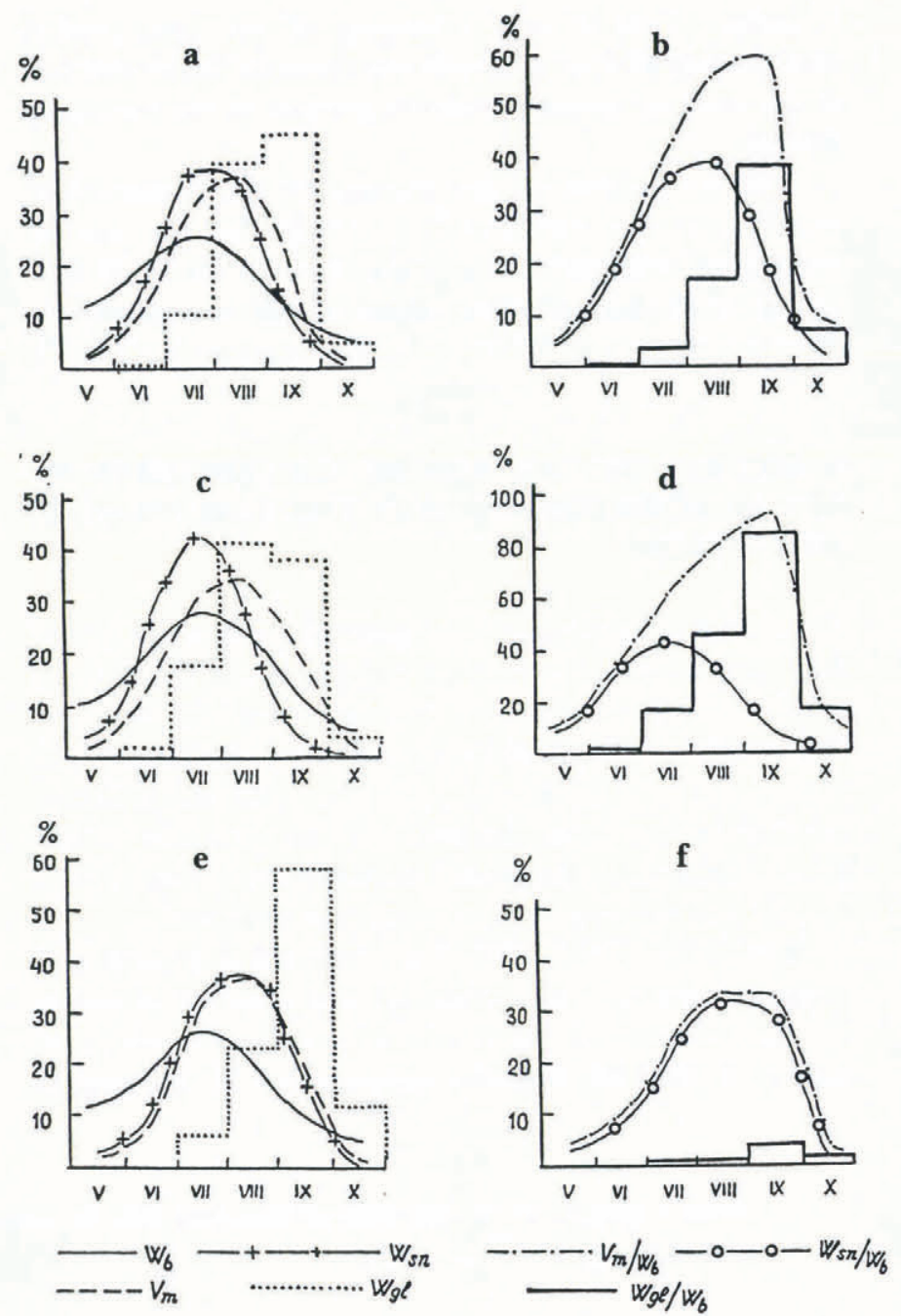

Fig. 2. Intra-seasonal distribution of run-off and components of the total melting of glaciers in the years of different water yield in the basin of the Vakhsh River. a and $b$ are the average flow years; $c$ and $d$ are the high-flow years; $e$ and $f$ are low-flow years. $W_{\mathrm{b}}$ is the relative part of the total river run-off, $V_{\mathrm{m}}$ is the relative part of the total melting, $W_{\mathrm{sn}}$ is the relative part of the snowmelt run-off from a glacierized area, $W_{\mathrm{gl}}$ is the relative part of the glacial run-off.

\section{GLACIO-HYDROLOGICAL INDICES OF THE EVOLUTION OF GLAGIATION IN THE PAMIRS AND GISSARO-ALAI MOUNTAINS AND THEIR CHANGES IN 1957-80}

A specific layer of run-off from the integrity of glaciers in a river basin is a rather useful index among quantitative indices which allow us to assess the hydrological regime of glacierized areas. Table 5 gives examples of average longterm specific layers of run-off from the glacierized areas of a number of river basins in Central Asia.

This table shows that the size of a glacierized area does not determine the value of the specific layer of glacial runoff. This fact smoothes the role of glaciation as the source of a river's nourishment, despite the large differences in sizes of their glacierized areas.

Thus, there is a 23.4 times difference between the areas of glaciers in the Pskem and Sarydias River basins, while average annual volumes of melt run-off differ by only 4.7 times. 
Table 5. Average specific layers of total annual run-off Mi from the glacierized areas of Central Asia (Mi = total melt volume/glaciation area)

\begin{tabular}{|c|c|c|c|}
\hline \multicolumn{2}{|c|}{ River basin } & $\begin{array}{l}\text { Glacierized area } \\
\qquad \mathbf{k m}^{2}\end{array}$ & $\begin{array}{r}M i \\
\mathrm{~m}\end{array}$ \\
\hline 1 & Pskem & 110.0 & 2.54 \\
\hline 2 & $\begin{array}{l}\text { Bolshoy and } \\
\text { Maly Naryn }\end{array}$ & 974.0 & 0.60 \\
\hline 3 & Saridjaz & 2581.0 & 0.51 \\
\hline 4 & Zeravshan (Matcha) & 472.8 & 2.60 \\
\hline 5 & Kizilsu & 641.4 & 1.85 \\
\hline 6 & Muksu & 2023.3 & 0.74 \\
\hline 7 & Surhob & 404.4 & 3.17 \\
\hline 8 & Obihingou & 802.7 & 2.08 \\
\hline
\end{tabular}

The lack of data on the inter-annual dynamics of glacierized areas predetermines the possible characteristics of their evolution effects on river run-off. Evidently, these characteristics should be considered as average longterm values and be expressed as a function of the morphometric parameters of glaciation. Under such conditions, annual specific layers of melting $\left(\mathrm{Mi}_{1}\right)$ and run-off $\left(\mathrm{Mi}_{2}\right)$ for a multitude of glaciers in a basin and the variation coefficients of annual volume of total glacial melting $\left(C_{\mathrm{v}_{1}}\right)$ and glacial run-off $\left(C_{\mathrm{v}_{2}}\right)$ are quite appropriate glacio-hydrological indices.

Table 6. Changes in average annual volumes of total melting $\Delta V_{1}$ and glacial run-off $\Delta V_{2}$ in the river basins of the Pamir mountains due to shrinkage of the glacierized area

\begin{tabular}{cr}
$\Delta V_{1}$ & $\Delta V_{2}$ \\
& \multicolumn{2}{c}{$\times 10^{6} \mathrm{~m}^{3}$} \\
\hline
\end{tabular}

\begin{tabular}{rlrr}
1 & Kizilsu West & -67.8 & -22.8 \\
2 & Muksu & -19.2 & -11.3 \\
3 & Fedchenko glacier & -5.1 & -1.3 \\
4 & Surhob & -119.9 & -27.2 \\
5 & Obihingou & -248.8 & -79.9 \\
6 & Vanch & -89.4 & -26.6 \\
7 & Jazgulem & -109.3 & -34.6 \\
8 & Bartang & -185.6 & -73.9 \\
9 & Kudara & -25.3 & -4.3 \\
10 & Murgab & -56.6 & -8.8 \\
11 & Gunt & -145.1 & -27.3 \\
12 & Shahdara & -38.8 & -7.2 \\
13 & Pjange right & & \\
& tributaries & -62.3 & -9.5 \\
& Pamir & -1172.2 & -335.1 \\
& & & \\
\hline
\end{tabular}

Statistical processing of experimental data gave us working expressions for the computation of the above indices as a function of mean weighted elevations of the glacier terminus and the firn line. A highly informative new parameter $\lambda$ entered into a series of independent variables. The variable $\lambda$ represents the ratio between the area from the glacier terminus to the firn line and the area from the glacier terminus to its elevation at $4.8 \mathrm{~km}$.

This index allows us to consider in an explicit form the effect of the distribution of glacierized areas in any elevation zone on intensity and volume of snow and icemelt. Investigation has also revealed that in the conditions of the Pamiro-Alai region an elevation of $4.8 \mathrm{~km}$ is the average upper limit of bare-ice melt in the period of 1935-85. Therefore, this is the upper limit for the expenditure of long-term reserves of glacierized areas. So, an assymptotic approach of $\lambda$ to some limit reflects the increase of ablation area which has favourable conditions

Table 7. Changes in average annual volumes of total melting $\Delta V_{1}$ and glacial run-off $\Delta V_{2}$ in the river basins of the Gissaro-Alai mountain range due to reduction of the glacierized area

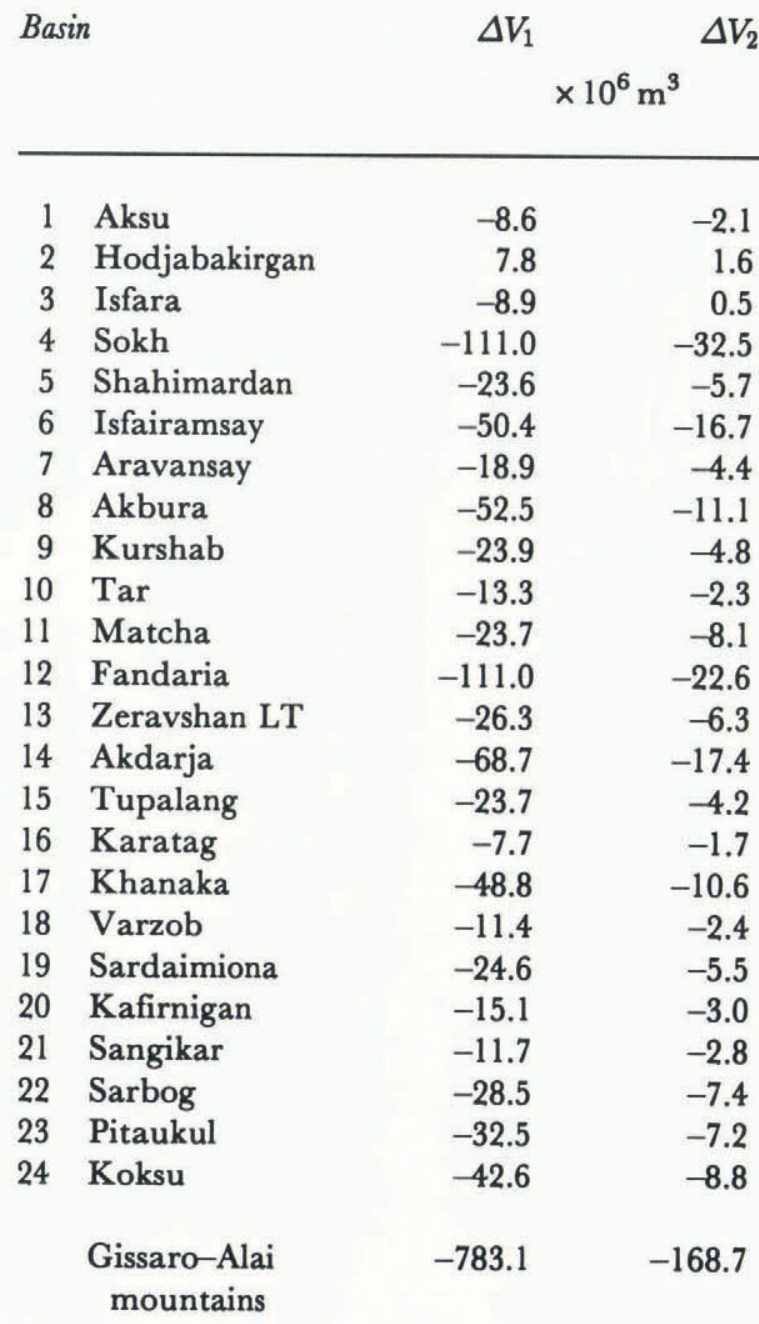

Note. 1. $\Delta V_{1}$ and $\Delta V_{2}$ in Tables 6 and 7 are changes in average total volume of glacial melting and run-off for 1957-80. 2. LT, left tributaries. 
for the formation of glacier run-off. For example, in the basin of the Zeravshan River only $1.6 \%$ of the total glacierized area is above $4.8 \mathrm{~km}$. Let us compare the basins of the Muksu and Saridjaz Rivers where $62.6 \%$ and $31.1 \%$ of glacierized areas, respectively, are above $4.8 \mathrm{~km}$. Such a large difference in the area distribution is the reason why the average value of $\mathrm{Mi}$ for the Zeravshan River exceeds the same ones in the glacierized regions of the Muksu and Saridjaz Rivers (see Table 5).

The expressions for calculating the statistical parameters of the glacial run-off series when $\lambda<2$ have the following general form:

$$
\begin{aligned}
& \mathrm{Mi}_{1}=\alpha_{1} Z_{\mathrm{fl}}^{2}+\alpha_{2} \lambda^{2}+\alpha_{3} Z_{\mathrm{fl}}+\alpha_{4} \lambda+\alpha_{5} Z_{\mathrm{f}} \lambda+\alpha_{0}, \\
& \mathrm{Mi}_{2}=\beta_{1} Z_{\mathrm{t}}^{2}+\beta_{2} \lambda^{2}+\beta_{3} Z_{\mathrm{t}}+\beta_{4} \lambda+\beta_{5} Z_{\mathrm{t}} \lambda+\beta_{0} \\
& C_{\mathrm{v}_{1}}=\gamma_{1} Z_{\mathrm{t}}^{2}+\gamma_{2} \lambda^{2}+\gamma_{3} Z_{\mathrm{t}}+\gamma_{4} \lambda+\gamma_{5} Z_{\mathrm{t}} \lambda+\gamma_{0}, \\
& C_{\mathrm{v}_{2}}=\delta_{1} Z_{\mathrm{t}}+\delta_{2} \lambda+\delta_{0}
\end{aligned}
$$

where $Z_{\mathrm{t}}$ and $Z_{\mathrm{fl}}$ are the elevations of the glacier terminus and firn line, respectively. $\mathrm{Mi}$ and $C_{\mathrm{v}}$ have been defined above; $\alpha_{0}-\alpha_{5}, \beta_{0}-\beta_{5}, \gamma_{0}-\gamma_{5}$ and $\delta_{0}-\delta_{2}$ are the empirical coefficients. The formulae for calculating the parameters of total-melt series are analogous.

Tables 6 and 7 give the results of the computation of the average long-term volume changes of total glacier melt and run-off in the separate river basins of the Pamirs and the Gissaro-Alai mountains due to the reduction in the glacierized area.

To study hydrometeorological conditions causing reduction of the glacierized area in the Pamirs and
Gissaro-Alai ranges and the decrease in glacial water yield, we calculated average values of the following parameters: run-off volumes of the Zeravshan, Vakhsh and Pjange Rivers in July-September and separately in August and September; sums of winter-spring precipitation and summer air temperature at the representative meteorological stations; indices of accumulation and ablation balance in the glacierized areas. All of the above-mentioned characteristics are given in Table 8 .

Analysis of data in Table 8 allows us to reach the following conclusions:

Despite the reduction of the glacierized area in the Pamirs, average run-off of the Vakhsh and Pjange Rivers in July-September 1966-80 was not less but increased compared with the preceding period of the same duration.

The decrease of run-off volume in July-September 1959-80 observed in the Zeravshan River basin (Gissaro-Alai range) was so insignificant that the average water yield of this basin can be considered invariable in both periods.

Reduction of the glacierized area and volumes of glacial nourishment in the river basins of the PamiroAlai mountains resulted in a negligible decrease in total run-off in September.

The average anomaly of the winter-spring precipitation in the later period of time is greater than the average anomaly of the air temperature; this is reflected in the change in the index sign for accumulation and and ablation balance in the basins

Table 8. Changes of hydrometeorological characteristics in the river basins of the Pamir and Gissaro-Alai mountains during the periods for which glaciation evolution was estimated

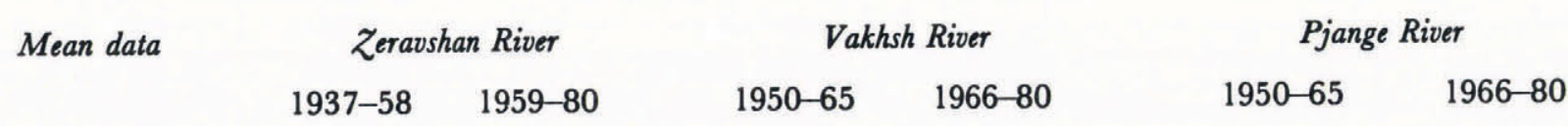

$\begin{array}{lc}1 \text { RV } \times 10^{6} \mathrm{~m}^{3} & \text { gs Dupuli } \\ \text { Jul-Sep } & 2693.2 \\ \text { Aug } & 979.3 \\ \text { Sep } & 486.4 \\ & \\ 2 \text { SP }(\mathrm{mm}) & \text { mst Dehauz } \\ & \text { Oct-Apr } \\ & 145.7\end{array}$

145.7

166.4

\begin{tabular}{lr}
\multicolumn{2}{c}{ gs Komsomolabad } \\
9455.0 & 9594.0 \\
3501.5 & 3585.5 \\
1895.7 & 1733.2
\end{tabular}

\section{mst Garm \\ Oct-Apr}

675.9

\begin{tabular}{cr}
\multicolumn{2}{c}{ gs Nizni Pjange } \\
14667.4 & 14974.4 \\
5061.6 & 5560.7 \\
2920.7 & 2845.7
\end{tabular}

mst Murgab
Jul-Sep

3 STemp $\left({ }^{\circ} \mathrm{C}\right) \quad \begin{aligned} & \text { mst Dehauz } \\ & \text { Jul-Sep }\end{aligned}$

$4 I_{\mathrm{B}}$
41.7

0.046
mst Fedchenko Glacier Jul-Sep

$-0.054 \quad 0.138$
0.046

Note. RV, run-off volume; SP, sum of precipitation; STemp, sum of mean monthly temperatures; $I_{\mathrm{B}}$, index of accumulation and ablation balance; gs, gauging station; mst, meteorological station. 
of the Zeravshan and Vakhsh Rivers, as well as an increase in the balance-index value in the Pjange River basin.

An average decrease of total volumes of glacial melt in the Pamirs is $\sim 5 \%$ of the average run-off of the Vakhsh and Pjange Rivers in July-August of 1966-80.

In the Zeravshan River basin (Gissaro-Alai range), the relative value of decrease in the average volume of total glacial run-off is negligibly small $(\sim 0.05 \%)$.

Therefore, reduction of the glacierized area in the Pamirs and the Gissaro-Alai ranges, as well as a decrease of water-yield volume, was not followed by an adequate decrease of average run-off volumes of the Zeravshan, Vakhsh and Pjange Rivers in July-September 1966-80. Here, the primary reason is that, compared with the previous period, there was higher accumulation of winter-spring snow and its intense melting in these areas had cleared it from the glaciers.

\section{REFERENCES}

Konovalov, V.G. 1979. Raschet i prognoz tayaniya lednikov Srednoy Azii [Computations and forecasts of melting and runoff of the Central Asian glaciers]. Leningrad, Gidrometeoizdat.

Konovalov, V.G. 1985. Tayaniye $i$ stok s lednikoo o basseynakh rek Sredney Azii [Melting and glacial runoff processes in the Central Asian river basins]. Leningrad, Gidrometeoizdat.

Mazo, A.B. and G.Ye. Glazyrin. 1986. Metod rascheta ob'ema stationargno gornogo lednika [A method of calculating the volume of a steady state mountain glacier]. Proceedings of the Central Asian Research Hydrometeorological Institute 117(198), 88-98.

Nye, J. F. 1952. A method of calculating the thicknesses of the ice-sheets. Nature, 169(4300), 529-530.

Steinhauser, P. 1970. Zur Bestimmung der Mächtigkeit der Ostalpengletscher. Oesterr. Wassenwirtsch., 22(11-12), 305-309.

Yerasov, N. V. 1968. Metod opredeleniya ob'yema gornykh lednikov [A method of calculating the volume of mountain glaciers]. Mater. Glyatsiol. Issled. Khron. Obsuzhdeniya 14, 307-308.

The accuracy of references in the text and in this list is the responsibility of the authors, to whom queries should be addressed. 